\title{
Water balance changes in the upper part of Dong Nai river basin
}

\author{
Thay đổi cân bằng nước ở thượng nguồn sông Đồng Nai
}

PHAM, Hung1,2*; VO, Le Phu²; LE, Van Trung²; OLIVIER, Paul A. ${ }^{3}$

${ }^{1}$ Department of Natural Resources and Environment Lam Dong Province, Vietnam; ${ }^{2}$ Faculty of Environment and Natural Resources, Ho Chi Minh City University of Technology - VNU HCM, Ho Chi Minh City, Vietnam; ${ }^{3}$ Empowering the Poor through Waste Transformation, 27/2bis Phu Dong Thien Vuong Street, Dalat. City, Vietnam.

\begin{abstract}
In recent decades, changes in land use and land cover (LULC) arising from socio-economic development, coupled with climate change, have severely undermined and compromised the environmental sustainability of the upper part of Dong Nai (UPDN) river basin. Assessing the long-term impacts of climate change and changes in LULC on hydrological conditions and water balance in the UPDN river basin is essential for sustainable watershed management. In the present study, Landsat images and SWAT (Soil and Water Assessment Tool) model were used to assess water balance changes due to changes of climate and LULC at three different intervals: 1994, 2004, and 2014. The results of Landsat images classification indicated that forest land was the main LULC type in the basin. In 1994 the forest cover was 706,803 ha (72.68\% of the total landmass). In 2004 the forest area dropped to 520,359 ha (53.51\%). In 2014 the forest area dropped further to 485,908 ha (49.97\%). The change in LULC has caused changes in the annual and peak water flows. The analysis of the results revealed that the effect of historical climate variations on water yield was greater than the LULC change. With the scenario of LULC 2014, the consumption of irrigation water was the highest and mainly in the dry season. The findings can provide useful information for decision-makers in planning and formulating policies for sustainable watershed management and climate change adaptation.
\end{abstract}

\begin{abstract}
Trong những thập niên gần đây, sự thay đổi về sử dụng đất và thực phủ (LULC) do những hoạt động phát triển kinh tế - xã hội cùng với biến đổi khi hậu đã đặt ra những thách thức cho sự bền vững về môi trường ở lưu vực thượng nguồn sông Đồng Nai (UPDN). Đánh giá các tác động lâu dài của biến đổi khí hậu và những thay đổi trong LULC đến điều kiện thủy văn và cân bằng nước là việc cần thiết cho quả̉n lý bền vững nguồn nước. Trong nghiên cứu này, các ảnh vệ tinh Landsat, công cu đánh giá đất và nước (SWAT) được sử dụng để đánh giá sự thay đổi cân bằng nước do sự thay đổi khí hậu và LULC tại ba thời điểm khác nhau 1994, 2004 và 2014. Kết quả phân loại các ảnh Landsat cho thấy rừng là loại thực phủ chính trong lưu vực. Diện tích rừng của năm 1994 là 706.803 ha (72,68\%). Diện tích rừng của năm 2004 đã giảm xuống còn 520.359 ha (53,1\%) và đến năm 2014 chỉ còn 485.908ha (49,97\%). Thay đổi sử dụng đất và thực phủ đã làm thay đổi chế độ thủy văn và dòng chảy đỉnh. Phân tích kết quả đã xác định rằng những sự thay đổi về điều kiện khi hậu trong quá khứ có ảnh hưởng đến lượng nước lớn hơn so với thay đổi về thực phủ. Với kịch bản LULC năm 2014, nhu cầu sử dụng nước tưới cho cây trồng là lớn nhất và chủ yếu trong mùa khô. Những kết quả đạt được trong nghiên cứu này sẽ cung cấp thông tin hữu ích cho các nhà hoạch định trong lập kế hoạch và ban hành chính sách cho quản lý lưu vực bền vững, thich ứng với biến đổi khí hậu.
\end{abstract}

Keywords: SWAT, Landsat, water yield, sediment load, water balance, upper part of Dong Nai

\section{Introduction}

Water balance relates to the balance between the input and output of water [1]. For an entire watershed, water balance refers to the balance between incoming water by precipitation, and outgoing water from evapotranspiration, groundwater recharge, and streamflow [2]. Due to population growth, socio-economic development and urbanization, water demand by agricultural, industrial, and municipal interests has increased, in some cases exceeding existing supplies. In addition, climate change has significantly affected the hydrological conditions, while the changes in land-use and land-cover (LULC) have continuously skewed the water balance.

Several methods and models have been developed to calculate water balance, such as the TMWB, VIC, TOPMODEL, HBV, MIKESHE, and SWAT (Soil and Water Assessment Tool) model. However, these depend on available baseline data such as meteorology, soil water characteristics, vegetation structure, and streamflow gauge data in the catchment, as well as several physical characteristics [2]. Each model has its own unique characteristics, and they all have various drawbacks [3]. 
In the above mentioned models, SWAT is a model with the wide range applications [4], and it has been generally accepted as a very robust and flexible interdisciplinary tool that can be used to simulate a variety of watershed problems, such as continuous simulations of water flow, soil erosion, nutrient and sediment transport $[5,6]$. Much research has been done wherein the SWAT model is used to evaluate simultaneous impacts of climate land use changes on hydrological conditions [7-10]. Nowadays, with developments of Remote Sensing (RS) and Geographic Information Systems (GIS) techniques, they provide a straightforward means to derive topographic features from digital elevation map (DEM) data, while RS data helps to identify spatial and temporal LULC changes [11]. Remote sensing creates comprehensive thematic maps based on the classification of satellite images by visual or computer-aided analysis to assess historical LULC changes [12].

The Dong Nai river basin is the largest national river basin and originates in the Central Highland region of Vietnam. The upper part of the Dong Nai (UPDN) river basin, a forest areas higher than the rest, plays a crucial role for sustainable socio-economic development of provinces in the Southeast region of Vietnam. In recent decades, rapid population growth has followed, thereby increasing the need for production land, agricultural land and residential land. According to the People's Committee of Lam Dong province [13], the forest area of Lam Dong in 2014 was reduced by about $8 \%$ compared to 10 years earlier. The upper part of Dong Nai mainly belongs to Lam Dong Province. The effects of historical changes in LULC due to socio-economic development, coupled with climate change on hydrological conditions and water balance, haven't been examined in detail yet.

Understanding the water balance plays an important role with respect to effective water resource management. The objectives of this study are (1) to determine the water balance changes based on climate variations and LULC changes of 1994, 2004, and 2014; (2) to calculate water resources and water demand on the basis of LULC of 2014 in the UPDN river basin.

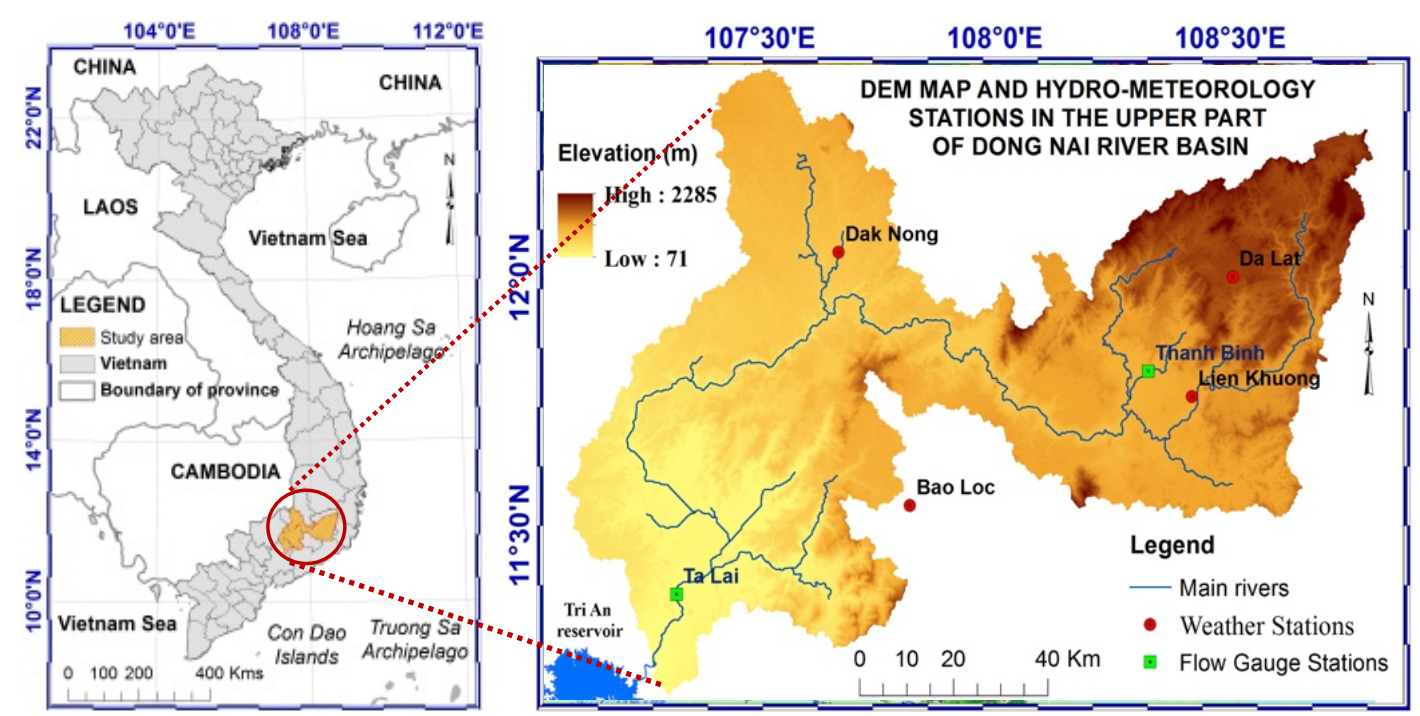

Figure 1. Location of the study area and its elevation $(m)$ pattern

\section{Material and method}

\subsection{Study area}

This study, in the upper part of the Dong Nai river basin (Figure 1), covers an area of 972,460 ha, a land mass that belongs mainly to Lam Dong province, separate, of course, from Dac Nong, Binh Phuoc, and Dong Nai provinces.

The river originates from the North of the Langbiang plateau, where there are high mountains with an elevation over 1,500 m above sea level. The region has a tropical monsoon climate regime influenced by altitude. There are two seasons, the rainy season from May to November, and the dry season from December to April of the following year. Over the past 33 years from 1981-2014, the average annual temperature was $22^{\circ} \mathrm{C}$, the annual precipitation was 2,500 mm, and the annual humidity was $83 \%$ [14].

\subsection{SWAT model description}

In recent years, hydrological models have been used increasingly to estimate land use and climate change impact assessments on runoff in order to implement water resources management strategies as well as flood control. Such models include AGNPS (Agricultural Nonpoint Source) [15-17], MIKE SHE simulation models (European Hydrological System Mode) [1822], WEPP (Water Erosion Prediction Project) [23-26], EUROSEM (European Soil Erosion Model) [27,28]. Among these foregoing models, SWAT has been a 
well-established model, and it has been used successfully in a wide range of environmental conditions and regions as well as being accepted by researchers and policy makers around the world [6,29].

Soil and Water Assessment Tool (SWAT) is a physically-based distributed hydrological model developed by Jeff Arnold for the USDA-Agricultural Research Service (USDA-ARS) and designed to estimate impacts of land management practices on water quantity and quality in complex watersheds with varying soil, land use, and management conditions over long periods of time. SWAT partitions a watershed into sub-basins or sub-watersheds connected by a stream network and further delineates each sub-watershed into Hydrological Response Units (HRUs) consisting of unique combinations of land use, soils, and management combinations. SWAT simulates the hydrology of a watershed into two phases. The first phase, the land phase of the hydrologic cycle, calculates the amount of water, sediment, nutrient and pesticide loads from each HRU and sums up to the level of sub-basins. The second phase, the routing phase of the hydrologic cycle, defines the movement of water, sediment and other non-point sources of pollution through the channel network to an outlet of the watershed $[5,30]$. The hydrological cycle is simulated in the SWAT model based on the water balance equation [30]:

$$
S W_{t}=S W_{0}+\sum_{i=1}^{t}\left(R_{d a y}-Q_{\text {suf }}-E_{a}-w_{a}-Q_{g w}\right)
$$

where $S W_{t}$ is the final soil water content. SWo is the initial soil water content on day i. t is the time (days). $R_{\text {day }}$ is the amount of precipitation on day $i$. Qsurf is the amount of surface runoff on day $i\left(\mathrm{~mm} \mathrm{H}_{2} \mathrm{O}\right)$. $E_{a}$ is the amount of evapotranspiration on day $i$. Wseep is the amount of water entering the vadose zone from the soil profile on day i. Qlat is the water percolation past bottom of the soil profile in the watershed for day i. $\mathrm{Q}_{\mathrm{gw}}$ is the amount of return flow on day i. All water units are in $\mathrm{mm}_{2} \mathrm{O}$.

In the present study, SWAT in version 2012 was used to estimate historical water yield in the UPDN river basin under conditions of climate change coupled with land cover, land cover change in 1994, 2004, and 2014. In addition, based on statistic data and modelling results, the study calculated total of water resources and water demand via the scenario of LULC of 2014.

\subsection{Dataset}

The key datasets required by the SWAT model are the Digital Elevation Model (DEM) map, the weather data, the soil map, the LULC map, and stream-flow [8,31]. The description of the main datasets is shown in Table 1.

Table 1. Spatial input data and monitoring data used to simulate and test SWAT model

\begin{tabular}{lll} 
Data & Resolution & Source \\
\hline $\begin{array}{l}\text { Digital Elevation } \\
\text { Model (DEM) map }\end{array}$ & $12.5 \mathrm{~m}$ & Downloaded from the NASA website: ttps://urs.earthdata.nasa.gov/users/new \\
\hline $\begin{array}{ll}\text { Weather } \\
\text { Soil map }\end{array}$ & Four stations & Obtained from 4 weather stations (Da Lat, Lien Khuong, Bao Loc, and Dac Nong) \\
\hline LULC & $30 \mathrm{~m}$ & $\begin{array}{l}\text { Obtained from the Department of Natural Resources and Environment (DONRE) of Lam } \\
\text { Dong province }\end{array}$ \\
\hline Stream-flow & Landsat TM/ETM/ OLI-TIRS, three time periods (1994, 2004, and 2014), downloaded from \\
\hline
\end{tabular}

\subsubsection{Digital Elevation Model}

The DEM map with 12.5-meter resolution can be downloaded from the NASA website: ttps://urs.earthdata.nasa.gov/users/new. The DEM was used to delineate the basin boundary, along with sub-basins.

\subsubsection{Climate data}

Climate data used in the SWAT model consists of daily rainfall, temperature, wind speed, humidity and evapotranspiration data. Climate data consists of daily rainfall, daily precipitation and daily maximum and minimum temperatures from 1984 to 2014 obtained from 4 weather stations (Da Lat, Lien Khuong, Bao Loc, and Dak Nong). The missing data in daily solar radiation, wind speed, and relative humidity were generated automatically by SWAT $[8,32]$. The spatial location of these stations could be sufficiently representative for the rainfall and temperature across the entire watershed area, see Figure 1.

\subsubsection{Soil data}

The SWAT model requires soil property data such as the texture, chemical composition, physical properties, available moisture content, hydraulic conductivity, bulk density and organic carbon content for the different layers of each 
soil type [33]. Soil data was obtained from the 1:100,000 soil map of the Department of Natural Resources and Environment (DONRE) Lam Dong province. The spatial distribution of classes is shown in Figure 6.

\subsubsection{Land use and land cover data}

The LULC maps, in a 10-year temporal interval, were derived from classifying Landsat images (Landsat 5 TM images in 1994, 2004 and Landsat-8 OLI/TIRS in 2014) $[\underline{5}, \underline{8}, 31,34]$. The selection of classification method depends on many factors, including ease of use, the interpretability of the classifier, speed, scalability, the kind of data, the statistical distribution of classes and target accuracy. Land cover classification methods of Landsat images have been developed over the last four decades [35]. Compared to visual approaches which classification was manual, modern classification methods based on pattern recognition techniques and implemented on computer-automated programs through artificial intelligence theories and machine learning have been developed and consequently resulted in many advantages. These unsupervised and supervised pixel-based classification methods are commonly grouped as parametric or non-parametric classifiers using maximum likelihood (ML) algorithm, Iterative Self-Organizing Data Analysis Technique (ISODAT) and K-Means classifier [35]. Based on actual conditions of the study area, the maximum likelihood (ML) algorithm in the ENVI Version 4.5 image processing software, a commonly used method derived from Landsat images [34,35], was applied to map LULCs for 1994, 2004 and 2014. An accuracy assessment of land cover classification, obtained by computing the confusion matrix in ENVI 4.5 software, showed an overall accuracy value of $77.7 \%$ for $1994,87.0 \%$ for 2004 , and $84.3 \%$ for 2014.

These LULC classes include (1) water bodies, (2) broadleaf evergreen forests, (3) mixed forests, (4) coniferous forests, (5) built-up residential areas, (6) annual agricultural land, and (7) perennial agricultural land. The kinds of LULC were coded to SWAT-Land-Use type respectively (1) WATR, (2) FRSE, (3) FRST, (4) PINE, (5) URML, (6) AGRR, (7) AGRC. In addition, three natural forests (broadleaf evergreen forest, mixed forest, coniferous forest) were combined together to assess forest changes.

\subsubsection{River discharge}

Daily and monthly stream-flow data from 1984 to 2014 were collected from the Thanh Binh and Ta Lai gauge stations located at the upstream and downstream of the basin. The stream-flow data is used for the calibration and validation of the model $[8, \underline{31}]$.

In additon, the main datasets to estimate water demand were based on the Statistical Yearbook of Lam Dong, Dong Nai, Binh Thuan, Binh Phuoc and Dak Nong provinces.

\subsection{Model evaluation}

To evaluate the simulated results of the SWAT model, the study used the coefficient of determination $\left(R^{2}\right)$ and the Nash-Sutcliffe efficiency $\left(E_{N S}\right)$ index. The value for $\mathrm{R}^{2}$ ranges from zero to one. If the $\mathrm{R}^{2}$ value is one, the result of simulation is perfect. If the $R^{2}$ value is zero, the result of simulation indicates no alignment between simulated and observed values. Meanwhile, values for $E_{\text {Ns }}$ range from - $\infty$ to one. The model results are satisfactory if the $E_{N S}$ values are greater than 0.5. Furthermore, $E_{N S}$ values between 0.5-0.65 are acceptable, values between 0.65-0.75 are good, and values that exceed 0.75 are very good $[31,36]$.

\subsection{Estimate water resources and demand}

\subsubsection{Water resources}

The water resources within a river basin consist of the discharge generated inside the river basin, the inflow coming from the upstream, the yield of reservoirs, the groundwater resources and the water transfers. In the UPDN river basin, water resources are mainly the discharge generated inside the river basin (runoff) and the yield of reservoirs. Runoff is calculated with the Soil and Water Assessment Tool (SWAT). The yield of reservoirs is calculated based on locally collected data [37].

\subsubsection{Water use}

The water demand within a river basin consists of the following components: population demand, agricultural demand, industrial demand, service sector demand and the minimum flow requirement (ecological water) [37]. The water demand of the population (domestic water demands) mainly includes water use for all residential needs and is usually estimated based on population numbers (urban and rural areas combined), per capita water consumption and water use efficiency [38]. In this study, per capita water consumption is estimated according to the Vietnam Construction Standard TCXDVN 33:2006 [39].

Agricultural water demand includes crop and livestock water demand $(F A O, 1998)[37,40]$. Industrial water demand is calculated based on the average amount of water needed for the production of a certain product. Water use for the service sector is defined as the amount of water needed per tourist per day [37]. The number of overnight stays of Vietnamese and international tourists per year are taken into account based on the provincial statistical Yearbook of Lam Dong, Dong Nai, Binh Thuan, Binh Phuoc and Dak Nong provinces. The Ecological water requirement is the minimum flow needed to sustain the basic ecological properties of a river. The ecological water requirement in a 
river basin is defined as the runoff at the Q95 percentile [41].

The water resources within a river basin consist of the discharge generated inside the river basin, the inflow coming from upstream, the yield of reservoirs, the groundwater resources and the water transfers. In the UPDN river basin, water resources consist mainly of the discharge generated inside the river basin (runoff) and the yield of reservoirs. Runoff is calculated with the Soil and Water Assessment Tool (SWAT). The yield of reservoirs is calculated based on the locally collected data [37].

\section{Results and discussion}

\subsection{Land use and land cover changes}

The classification results of Landsat images indicated that forests have been the dominant land cover type of the UPDN river basin. The rate of forest cover in 1994, 2004, and 2014 was 706,803 ha (72.68\%), 520,359 ha (53.51\%), and 485,908 ha (49.97\%), respectively, see Figure 3, Figure 4 , and Figure 5.

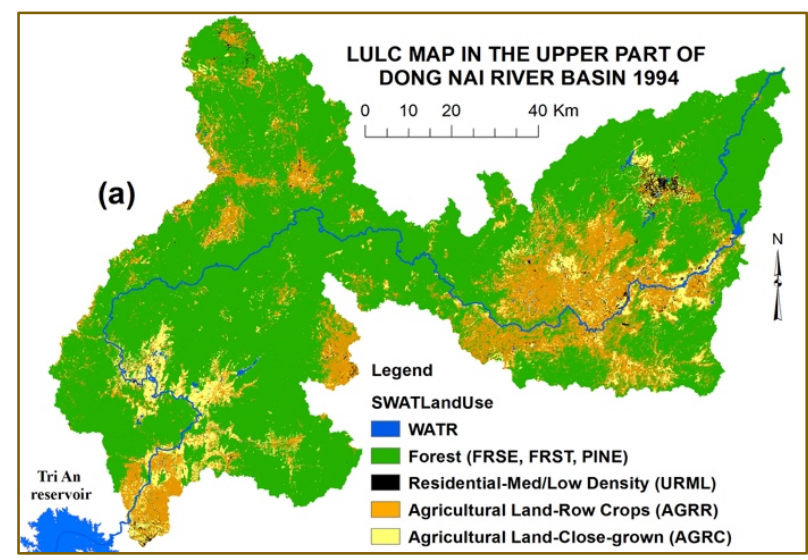

Figure 3. LULC map of 1994 (a)

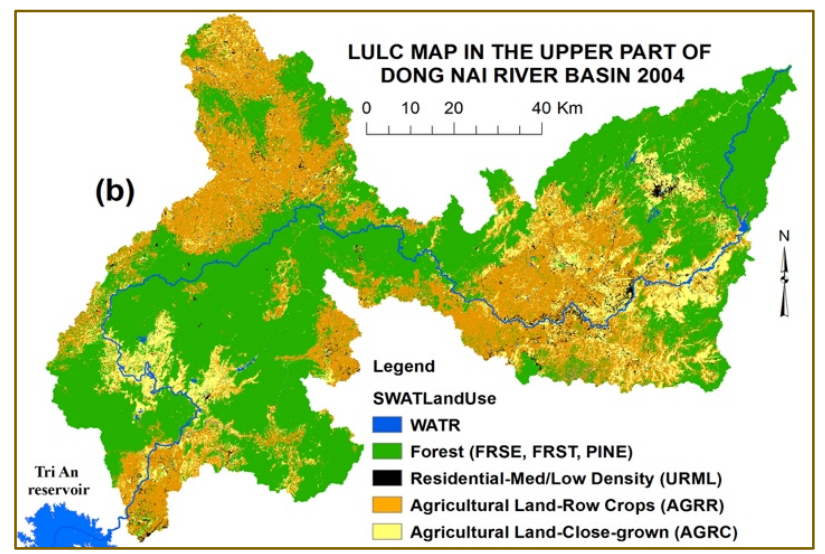

Figure 4. LULC map of 2014 (c)

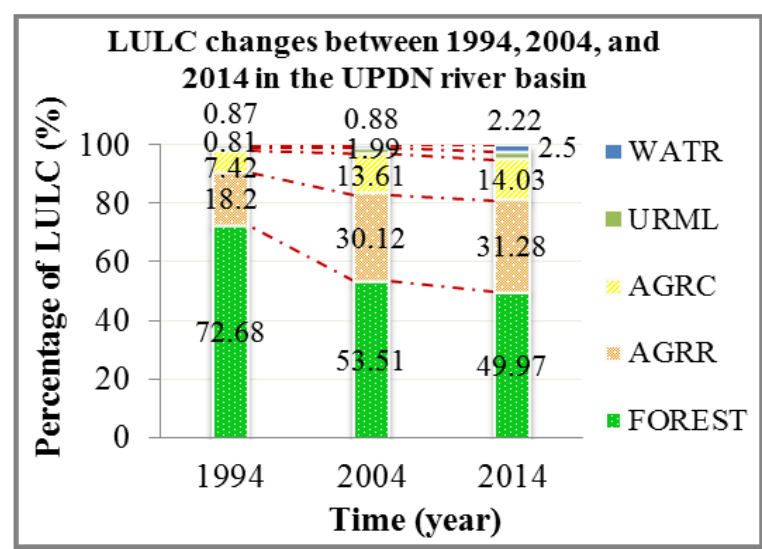

Figure 2. Changes in LULC of 1994, 2004, and 2014

Changes in LULC of 1994, 2004, and 2014 are shown in Figure 2. Over the 20 years from 1994 to 2014, 220.895 ha $(22,71 \%)$ of forest have been lost. 186,444 ha (19.17\%) have been lost in the period from 1994 to 2004, and 34,451 ha (3.82\%) have been lost in the period from 2004 to 2014 . There has been an increase in agricultural land use: from 249,230 ha $(25.62 \%)$ in 1994, to 425,239 ha (43.73\%) in 2004, to 440,688 ha (45.31\%) in 2014.

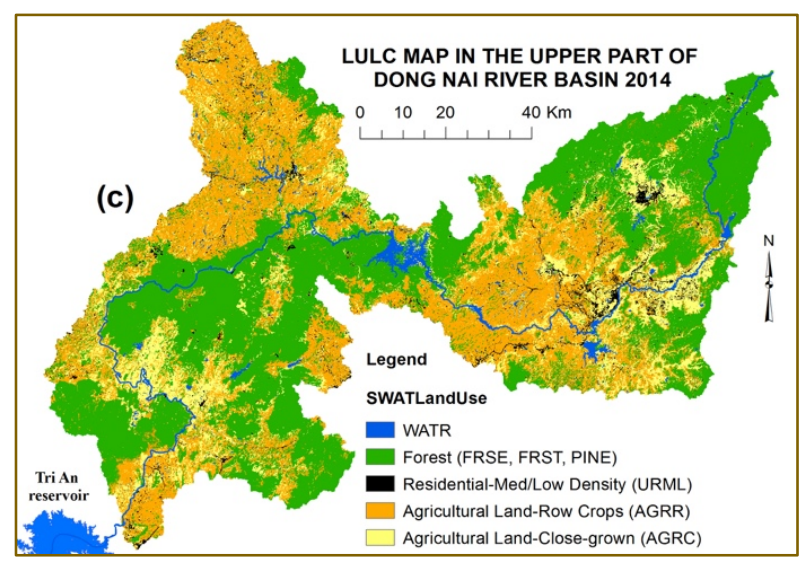

Figure 5. LULC map of 2004 (b)

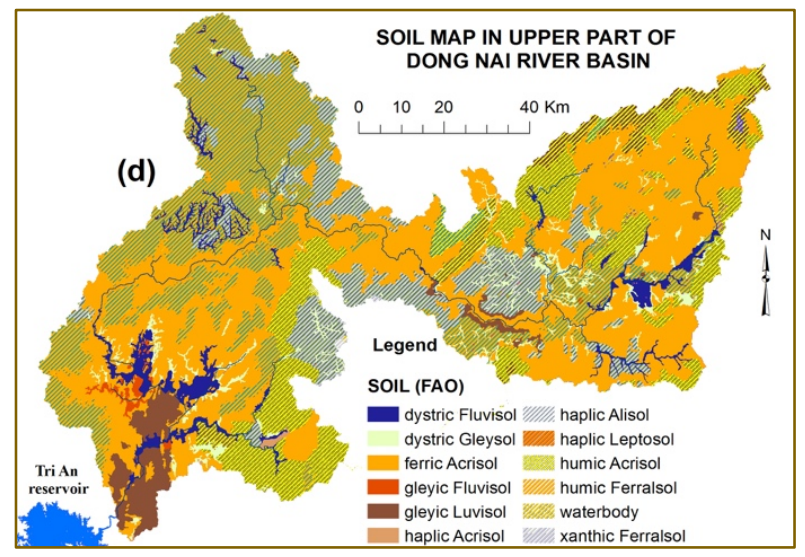

Figure 6. Spatial distribution of each soil type

The model calibration and validation were conducted according to two local stream-flow gauge stations, one in 
Thanh Binh (upper stream) and the other in Ta Lai (lower stream). Simulated and observed stream-flow data from January of 2000 to December of 2010 were used for model calibration, based on the LULC map of 2004. The simulated and observed stream-flow during the calibration period achieved relatively good results with an R2 of 0.811 and an Ens of 0.809 for the upper stream, and an R2 of 0.771 and an Ens of 0.765 for the lower stream. The simulated and observed stream-flow during the validation period of 1984 to 2014 gave rise to results with an Ens of 0.712 and a R2 of 0.713 , an Ens of 0.712 and a R2 of 0.713 for the upper and lower streams, respectively.
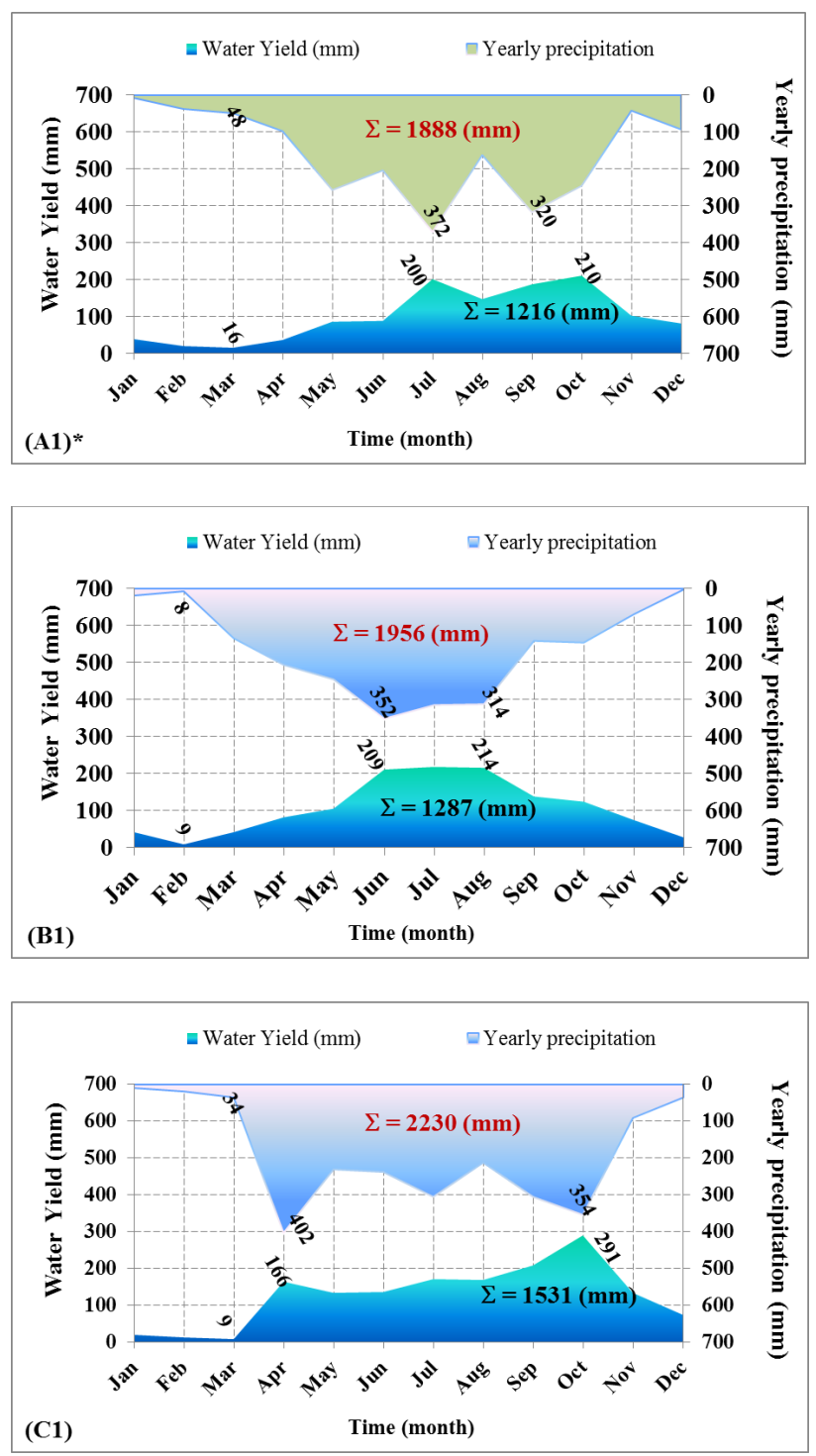

Figure 7. Changes in water yield based on scenarios 1

In scenario 1 (LULC of 1994 applied to climatic conditions of 1994, 2004, and 2014), see Figure 7. With the same conditions of LULC, the graphs show that monthly and yearly water yield depended mainly on the distribution of annual rainfall. With the historical scenario (A1)*, LULC of 1994 and climatic conditions in 1994, the graphs show that the distribution of water yield in the river basin was divided into two distinct seasons, the rainy season from April to

\subsection{Water balance changes}

To estimate the water balance changes based on climate and LULC variations, three sets of climate and LULC data (1994, 2004, and 2014) were set up to simulate the hydrological responses by using the SWAT model. Figure 7, Figure 8, and Figure 9 show changes in water yield based on the LULCS of 1994, 2004 and 2014 in conjunction with climatic conditions in 1994, 2004, and 2014. The symbol (*) in each figure is historical scenarios of climatic conditions with LULC.
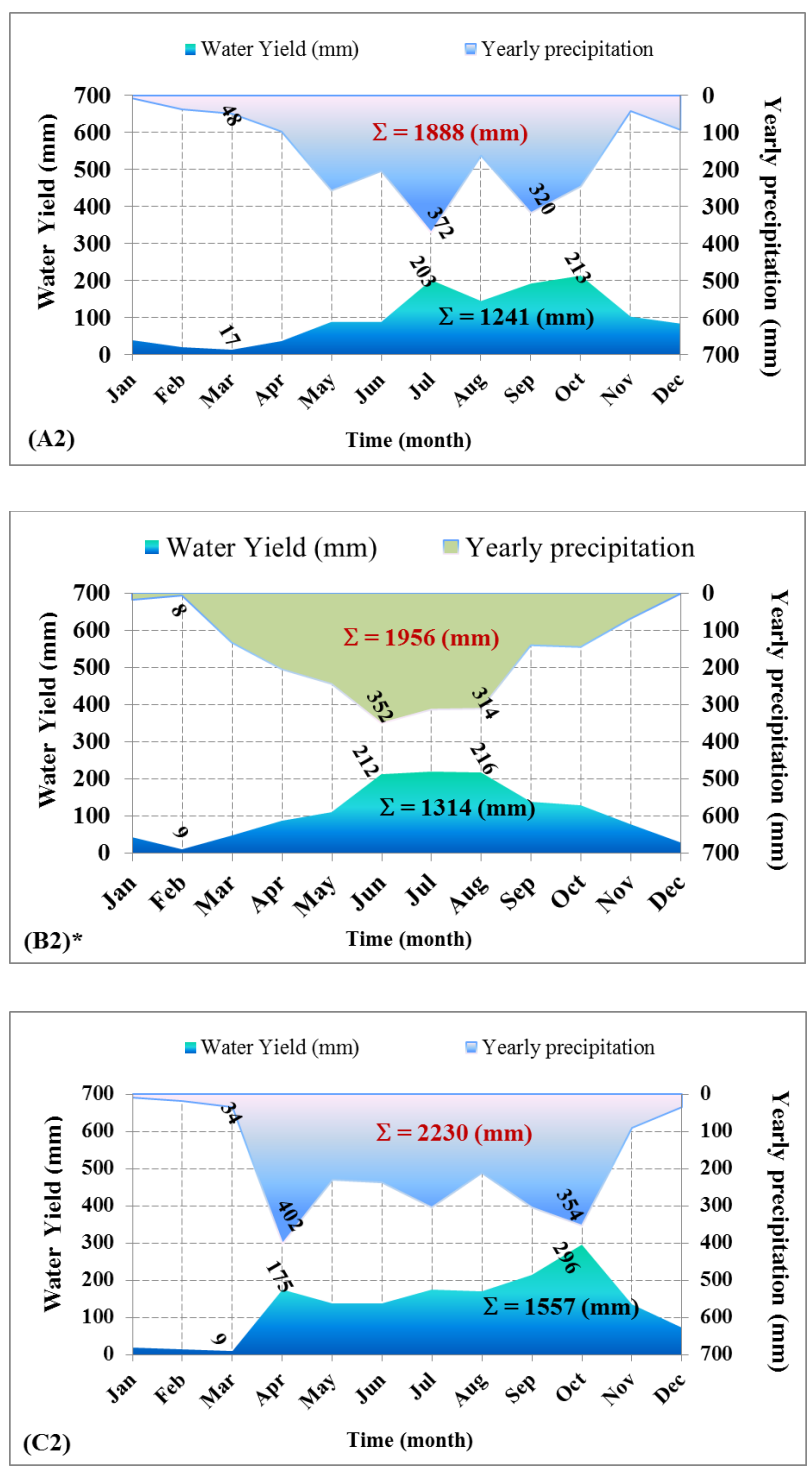

Figure 8. Changes in water yield based on scenarios 2

November and the dry season from December to March the following year. The monthly lowest and highest water yields were March (16 mm) and October $(210 \mathrm{~mm})$, respectively. With the LULC of 1994 applied to climatic conditions of 2004, the monthly lowest water yield was February $(9 \mathrm{~mm})$ and the monthly highest water yield was August (214mm). Meanwhile, under the LULC of 1994 with the 
hypothetical climatic conditions in 2014, these figures were $9 \mathrm{~mm}$ in March and $291 \mathrm{~mm}$ in October, respectively.
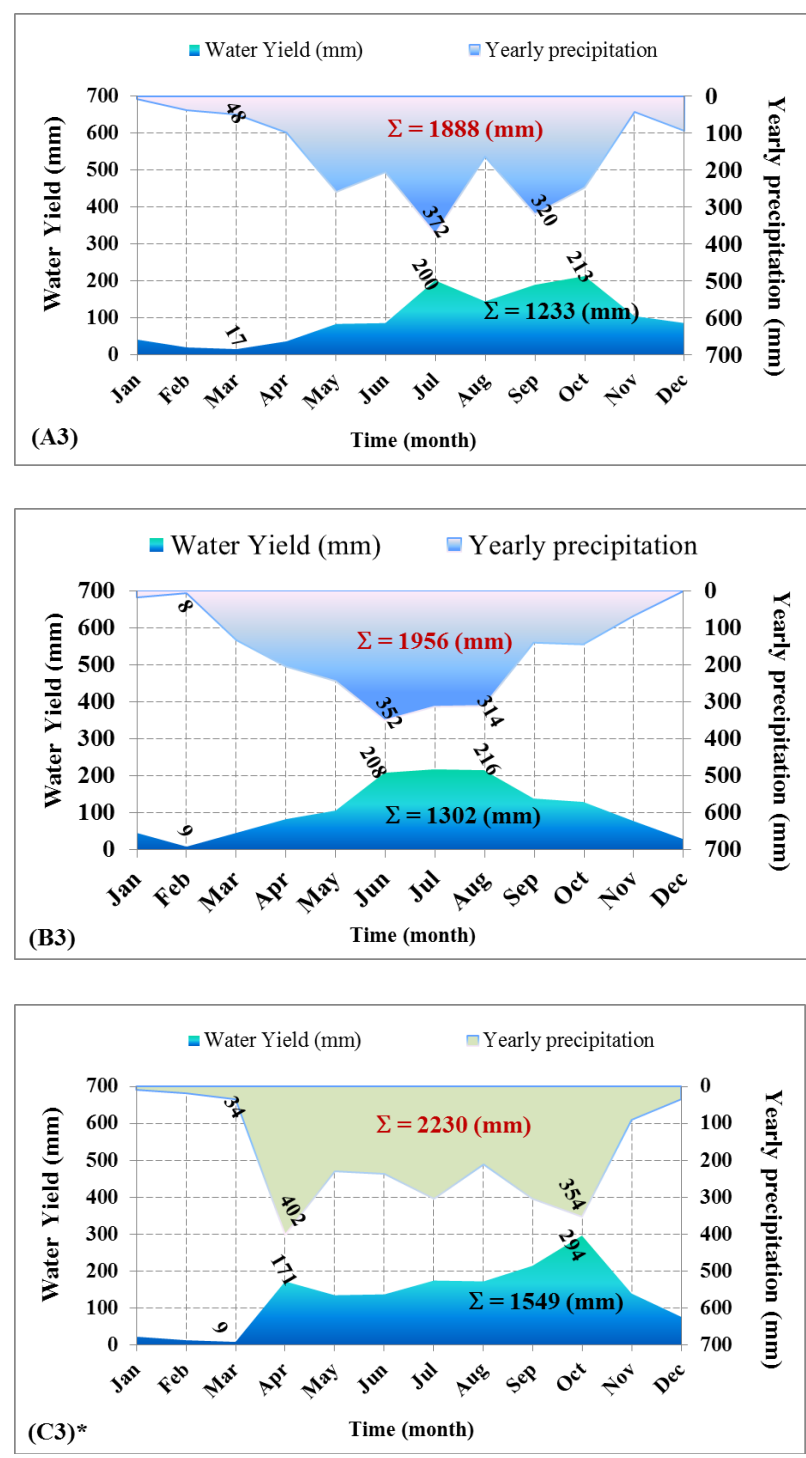

Figure 9. Changes in water yield based on scenarios 3

In scenario 2 (LULC of 2004 applied to climatic conditions of 1994, 2004, and 2014), see Figure 8. With the historical scenario (B2)*, land use in 2004 and climatic conditions in 2004, the results show the monthly lowest and highest water yield were February $(9 \mathrm{~mm})$ and August $(216 \mathrm{~mm})$, respectively. With the LULC of 2004 applied to conditions of climate and precipitation of 1994, the monthly lowest water yield was March $(19 \mathrm{~mm})$ and the monthly highest water yield was October $(213 \mathrm{~mm})$. Whereas, in a hypothetical scenario of a LULC in 2004, with the climatic conditions as in 2014, these figures were $9 \mathrm{~mm}$ in March and 296mm in October, respectively.

In scenario 3 (LULC of 2014 applied to climatic conditions of 1994, 2004, and 2014), see Figure 9. With the historical scenario (C3)*, LULC of 2014 and climatic conditions in 2014, the results show the monthly lowest and highest water yield were March ( $9 \mathrm{~mm}$ ) and October (294mm), respectively. With the LULC of 2014 applied to climatic conditions of 1994, the monthly lowest water yield was March (17mm) and the monthly highest water yield was October $(213 \mathrm{~mm})$. On the other hand, under the LULC of 2014 with the climatic conditions in 2004, these figures were 9mm in February and $216 \mathrm{~mm}$ in October, respectively.

In general, with the same climate conditions, the results show that LULC change insignificantly affected the monthly flow regime in 1994, 2004, and 2014. The change in LULC has caused small fluctuations in the annual flow and peak flow regimes. These results match with the previous studies (Can et al., 2015) [31], which showed that moderate land use changes give rise to minor changes in the water yield. In addition, the results show that the LULC changes also have effects on water yield. With precipitation at 1,888 $\mathrm{mm}$ in 1994, water yield was 1,216 mm, 1,241 mm, and 1,533 mm for LULC scenarios of 1994, 2004, and 2014, respectively. The decrease of forest area of 2004 compared to 1994 was a reason for the decrease in evapotranspiration and increase of water yield (1,216 mm of 1994 compared to 1,241 $\mathrm{mm}$ of 2004). This is similar to the findings in the Be River and Cau River catchment in Vietnam, conducted by (Phan et al., 2011) [42] and (Khoi and Suetsugi, 2014) [34]. The present study result matches fairly closely previous findings conducted by (Truong et al., 2018) [43], which concluded that the conversion of forests to agricultural land led to an immediate increase in total discharge. Then water yield decreased in 2014 compared to 2004 (1,533 $\mathrm{mm}$ of 2014 and 1,241 $\mathrm{mm}$ of 2004). The reason was due to the development of agricultural crops such as coffee, tea and reforestation [43], so that evapotranspiration increased.

\subsection{Estimate water resources and demand}

In view of the LULC 2014 over the entire basin, the yearly total water resource was 25.53 billion cubic meters and the yearly total water use was 2.32 billion cubic meters. The consumption of irrigation water was the highest at $68.2 \%$ compared to the rest. This consumption of irrigation significantly changed between the seasons $(70.5 \%$ in the dry season compared to $29.5 \%$ in the rainy season).

\section{Conclusion}

The analysis of these results shows that forest area was the dominant land cover type of the UPDN river basin. The forest cover was reduced enormously in the 20 years from 1994 to 2014, with nearly 23\% of the forest area lost. The results indicated that climate change and change in LULC has fluctuated (increased and decreased) in water yield for the whole watershed in 1994, 2004 and 2014. The changes in water yield (stream-flow) have mainly been driven by historical climate variations. There was a big difference in water yield between the two seasons of the year, with around $80 \%$ of water yield generated during the rainy season compared to $20 \%$ during the dry season. Irrigation water has been the dominant water use type of the UPDN river basin. 
Assessment of water balance change is one of the major factors for sustainable water resource management and planning in the context of climate change. The findings can provide useful information for decision-makers in formulating policies, in developing counterpart measures for climate change, and in adjusting for sustainable watershed development and management.

\section{References}

[1] Nugroho, P.; Marsono, D.; Sudira, P.; Suryatmojo, H. In Impact of land-use changes on water balance, The 3rd International Conference on Sustainable Future for Human Security (SUSTAIN 2012), Kyoto University, Japan, 2013; Published by Elsevier: Kyoto University, Japan, pp $256-262$.

[2] Suryatmojoa, H.; Fujimoto, M.; Yamakawa, Y.; Kosugi, K.i.; Mizuyama, T. Water balance changes in the tropical rainforest with intensive forest management system. International Journal of Sustainable Future for Human Security 2013, 1, 56-62.

[3] Devi, G.K.; P, G.B.; S, D.G. A review on hydrological models. Aquatic Procedia 2015, 4, 1001 - 1007.

[4] Borah, D.K.; Bera, M. Watershed-scale hydrologic and nonpoint-source pollution models: Review of mathematical bases. American Society of Agricultural Engineers 2003, 46, 1553-1566.

[5] Huang, T.C.C.; Lo, K.F.A. Effects of land use change on sediment and water yields in yang ming shan national park, taiwan. Environments 2015, 2, 32-42.

[6] Gassman, P.W.; Reyes, M.R.; Green, C.H.; Arnold, J.G. The soil and water assessment tool: Historical development, applications, and future research directions. American Society of Agricultural and Biological Engineers 2007, 50, 1211-1250.

[7] Khoury, A.E.; Seidou, O.; Lapen, D.R.; Que, Z.; Mohammadian, M.; Sunohara, M.; Bahram, D. Combined impacts of future climate and land use changes on discharge, nitrogen and phosphorus loads for a canadian river basin. Journal of Environmental Management 2015, 151, 76-86.

[8] Mango, L.M.; Melesse, A.M.; McClain, M.E.; Gann, D.; Setegn, S.G. Land use and climate change impacts on the hydrology of the upper mara river basin, kenya: Results of a modeling tudy to support better resource management. Hydrology and Earth System Sciences 2011, 15, 2245-2258.

[9] Zhu, C.; Li, Y. Long-term hydrological impacts of land use/land cover change from 1984 to 2010 in the little river watershed, tennessee. International Soil and Water Conservation Research 2014, 2, 11-22.

[10] Schilling, K.E.; Jha, M.K.; Zhang, Y.-K.; Gassman, P.W.; Wolter, C.F. Impact of land use and land cover change on the water balance of a large agricultural watershed: Historical effects and future directions. Water Resource Research 2008, 44, 1-12.

[11] Ozcan, A.U.; Erpul, G.; Basaran, M.; Erdogan, H.E. Use of usle/gis technology integrated with geostatistics to assess soil erosion risk in different land uses of indagi mountain pass-c, ankırı, turkey. Environ Geol 2007, 007-0779, 254-266.

[12] Foody, G.M. Status of land cover classification accuracy assessment. Remote Sensing of Environment 2002, 80, 185- 201.

[13] People's Committee of Lam Dong province. Decision no. 299/qd-ubnd dated 28/1/2015 on reporting the results offorest investigation of lam dong province in 2014; Dalat, 2015.

[14] Statistical Bureau of Lam Dong province. Statistical yearbook of lam dong province. Lam Dong Satistical Office: Da Lat, Lam Dong, Viet Nam, 2015.

[15] Young, R.A.; Onstad, C.A.; Bosch, D.D.; Anderson, W.P. Agnps: A non-point-source pollution model for evaluating agricultural watersheds. Juornal of Soil and Water Conservation 1989, 44, 168-173.

[16] Jianchang, L.; Luoping, Z.; Yuzhen, Z.; Huasheng, $H$.; Hongbing, D. Validation of an agricultural non-point source (agnps) pollution model for a catchment in the jiulong river watershed, china. Journal of Environmental Sciences 2008, 20, 599-606.

[17] Naik, D.; Kumar, P.; Deshmukh, A. Runoff and sediment yield prediction using agriculture non-point source (agnps) model in ata-gad watershed, uttarakhand, india. International Journal of Advanced Remote Sensing and GIS 2018, 7, 2551-2559.

[18] Golmohammadi, G.; Prasher, S.; Madani, A.; Rudra, R. Evaluating three hydrological distributed watershed models: Mike-she, apex, swat. Hydrology 2014, 1, 2039.

[19] Zhiqiang Zhang, S.W., Ge Sun, Steven G. McNulty, Huayong Zhang, Jianlao Li,; Manliang Zhang, E.K., and Peter Strauss2. Evaluation of the mike she model for application in the loess lateau, china. Journal of American water resource association 2008, 44, 1108-1120.

[20] Suman, A.; Akther, F. Investigation of water balance at catchment scale using mike-she. International Journal Of Engineering And Computer Science 2014, 3, 88828887.

[21] Zhou, X.; Helmers, M.; Qi, Z. Modeling of subsurface tile drainage using mike see. American Society of Agricultural and Biological Engineers 2013, 29.

[22] Liuxin; Dian-wu, W.; Dao-cai, C.; Yangning. Runoff simulation in semi-humid region by coupling mike she with mike 11. The Open Civil Engineering Journal 2015, 9, 840-845.

[23] Baigorria, G.A.; Romero, C.C. Assessment of erosion hotspots in a watershed: Integrating the wepp model 
and gis in a case study in the peruvian andes. Environmental Modelling \& Software 2007, 22, 1175-1183.

[24] Narimani, R.; Erfanian, M.; Nazarnejad, $H_{\text {.; }}$ Mahmodzadeh, A. Evaluating the impact of management scenarios and land use changes on annual surface runoff and sediment yield using the geowepp: A case study from the lighvanchai watershed, iran. Environ Earth Sci 2017, 76, 1-15.

[25] Ahmadia, H.; Taheri, S.; Feiznia, S.; Azarnivand, H. Runoff and sediment yield modeling using wepp in a semi-arid environment (case study: Orazan watershed). DESERT 2011, 16, 5-12.

[26] Pieri, L.; Bittelli, M.; Wu, J.Q.; Dun, S.; Flanagan, D.C.; Pisa, P.R.; Ventura, F.; Salvatorelli, F. Using the water erosion prediction project (wepp) model to simulate field-observed runoff and erosion in the apennines mountain range, italy. Journal of Hydrology 2007, 336, 84- 97.

[27] Centeri, C.; Barta, K.; Jakab, G.; Szalai, Z.; Bíró, Z. Comparison of eurosem, wepp, and medrush model calculations with measured runoff and soil-loss data from rainfall simulations in hungary. Journal of Plant Nutrition and Soil Science 2009, 172, 789-797.

[28] Rosenmund, A.; Confalonieri, R.; Roggero, P.P.; Toderi, M.; Acutis, M. Evaluation of the eurosem model for simulating erosion in hilly areas of central italy. Rivista Italiana di Agrometeorologia 2005, 2, 15-23.

[29] Shi, P.; Chen, C.; Srinivasan, R.; Zhang, X.; Cai, T.; Fang, X.; Qu, S.; Chen, X.; Li, Q. Evaluating the swat model for hydrological modeling in the xixian watershed and a comparison with the xaj model. Water Resour Manage 2011, 25, 2595-2612.

[30] Neitsch, S.L.; Arnold, J.G.; Kiniry, J.R.; Williams, J.R. Introduction and history. In Soil and water assessment tool theoretical documentation version 2009, Texas Water Resources Institute Technical Report No. 406: Texas A\&M University System College Station, Texas 77843-2118, 2011; pp 6-10.

[31] Can, T.; Xiaoling, C.; Jianzhong, L.; Gassman, P.W.; Sabine, S.; José-Miguel, S.P. Assessing impacts of different land use scenarios on water budget of fuhe river, china using swat model. Int J Agric \& Biol Eng 2015, 8, 95-109.

[32] Jha, M.K.; Gassman, P.W.; Arnold, J.G. Water quality modeling for the raccoon river watershed using swat. Transactions of the ASAE 2007, 50, 479-493.

[33] Setegn, S.G.; Srinivasan, R.; Melesse, A.M.; Dargahi, B.
Swat model application and prediction uncertainty analysis in the lake tana basin, ethiopia. Hydrology Processing 2010, 23, 3738-3750.

[34] Khoi, D.N.; Suetsugi, T. Impact of climate and land-use changes on hydrological processes and sediment yield - a case study of the be river catchment, vietnam. Hydrological Sciences Journal 2014, 59, 1095-1108.

[35] Phiri, D.; Morgenroth, J. Developments in landsat land cover classification methods: A review. Remote Sensing 2017, 9, 1-25.

[36] Moriasi, D.N.; Arnold, J.G.; Liew, M.W.V.; Bingner, R.L.; Harmel, R.D.; Veith, T.L. Model evaluation guidelines for systematic quantification of accuracy in watershed simulations. Transactions of the ASABE 2007, 50, 885-900.

[37] Stolpe, H. Planning and decision support tools for integrated water resources management. Ruhr-Universitat Bochum Printing Center: Bochum, Germany, 2011.

[38] Xiao-jun, W.; Jian-yun, Z.; Shamsuddin, S.; Rui-min, H.; Xing-hui, X.; Xin-li, M. In Potential impact of climate change on future water demand in yulin city, northwest china, Mitigation and Adaptation Strategies for Global Change, Dordrecht, Netherlands, 2013; Springer Science+Business Media: Dordrecht, Netherlands, pp 119.

[39] Vietnam Ministry of Construction (MOC). Construction standards tcxdvn 33:2006, water supply - pipeline networks and facilities-design standards. Ha Noi, Vietnam, 2006; pp 1-158.

[40] Allen, R.G.; Pereira, L.S.; Raes, D.; Smith, M. Fao irrigation and drainage paper no. 56, crop evapotranspiration (guidelines for computing crop water requirements). 1998.

[41] Vietnam Ministry of Natural Resources and Environment (MONRE). Circular 64/2017/tt-btnmt regulations on determining minimum flows in rivers, streams and downstream of reservoirs and dams. Ha Noi, Vietnam, 2017; pp 1-8.

[42] Phan, D.B.; Wu, C.C.; Hsieh, S.C. Impact of climate change on stream discharge and sediment yield in northern viet nam. Water Resources 2011, 38, 827836.

[43] Truong, N.C.Q.; Nguyen, H.Q.; Kondoh, A. Land use and land cover changes and their effect on the flow regime in the upstream dong nai river basin, vietnam. Water 2018, 10,1-1. 